\title{
Acute Toxicity of Cypermethrin, a Synthetic Pyrethroid to Estuarine Clam Katelysia opima (Gmelin) and Its Effect on Oxygen Consumption
}

\author{
Madhura Mukadam, Arvind Kulkarni \\ Department of Zoology, R.P. Gogate College of Arts and Science and R.V. Jogalekar College of Commerce, \\ Ratnagiri, India \\ Email: madhuramukadam111@gmail.com, drarvindkulkarni13@rediffmail.com
}

Received 11 August 2014; revised 25 September 2014; accepted 10 October 2014

Copyright @ 2014 by authors and Scientific Research Publishing Inc.

This work is licensed under the Creative Commons Attribution International License (CC BY). http://creativecommons.org/licenses/by/4.0/

\section{cc) (i)

\section{Abstract}

The impact of acute exposure of Cypermethrin on the rate of oxygen consumption of the estuarine clam, Katelysia opima was studied. After 12, 24, 36, 48, 60, 7284 and $96 \mathrm{~h}$ of exposure to acute concentration, the average oxygen consumption in $\mathrm{LC}_{0}$ group was $0.215,0.305,0364,0.355,0.362$, $0.376,0.313,0.305,0.297(\mathrm{ml} / \mathrm{L} / \mathrm{hr} / \mathrm{gm})$ and in $\mathrm{LC}_{50}$ group it was $0.210,0.299,0.356,0.247,0.217$, $0.244,0.203,0.186,0.174(\mathrm{ml} / \mathrm{L} / \mathrm{hr} / \mathrm{gm})$. It was observed that the rate of oxygen consumption fluctuated with an increase in the exposure period. The decrease was maximum in $\mathrm{LC}_{50}$ group as compared to $\mathrm{LC}_{0}$ group.

\section{Keywords}

Cypermethrin, Katelysia opima, $\mathrm{LC}_{0}, \mathrm{LC}_{50}$, Oxygen Consumption

\section{Introduction}

Water is one of the precious liquid of the natural resources available. A plentiful supply of clean water is essential for survival of human being, plants and animals. The disposal of industrial and agricultural waste directly into the aquatic medium burdens the ecosystem [1]. Environmental pollution is one of the undesirable side effects of industrialization and an important aspect of environmental degradation [2]. The pollutants associated with the industrial effluents are organic matter, inorganic dissolved solids, fertilizers, thermal constituents in the form of heat suspended solids, microorganisms and pathogens. Among these pollutants, organic pollutants de- 
crease the level of dissolved oxygen in the water bodies. The disposal of these waste materials or waste water leads to contamination of rivers, lakes, and chronically affects the flora and fauna [3]. The exotic organic chemicals include surfactant in detergents, pesticides, various industrial products and the decomposition products of other organic compounds. Many of these are non biodegradable and are degraded only at a very slow rate. Some of these compounds have been found to be toxic to fish at very low concentration [4]. Pesticides are spreading over agricultural crops, throughout the year with different formulations and with different modes affect aquatic inhabitants. Presence of pesticide in streams and lakes is largely due to the runoff from agricultural fields and outfall from pesticide manufacturing factories [5]. Pesticides are not highly selective but are generally toxic to many non-target organisms. The aquatic environment is also polluted by pesticides and it leads to many changes in organism physiology [6]. Pesticides are indicated to cause respiratory distress or even failure by affecting respiratory centers of the brain or the tissue involved in breathing. The effect of toxicants on the respiration of fishes and invertebrates has received widespread attention and were reviewed by [7] [8]. Aquatic organisms like prawns, fish, bivalve, crab respire through gills. Such respiratory surfaces frequently encounter harmful pollutant present in water in different forms. These pollutants may lead to the alteration in the normal respiratory area which causes reduction in oxygen consumption and physiological imbalance in the organism [9].

The activity of animal can be measured in terms of oxygen uptake. Aquatic animals have to pass large quantities of water over their respiratory surface and are subjected to relatively greater risk of exposure to the toxic substances [10]. Depletion in oxygen content occurs in the medium when pesticides, chemicals, sewage and other effluents containing organic matter are discharged into water bodies. Pesticides at sublethal concentrations present in the aquatic environment are too low to cause rapid death directly, but may affect the functioning of the organisms, disrupt normal behavior and reduce the fitness of natural populations. In the aquatic environment, one of the most important manifestations of the toxic action of chemical is the over stimulation or depression of respiratory activity.

The review of literature shows that, there is no adequate information about the effect of pesticide on respiratory metabolism of estuarine clam, Katelysia opima. Hence the present study was carried out to study the alteration in the rate of oxygen consumption in estuarine clam, Katelysia opima after exposure to acute doses of Cypermethrin.

\section{Materials and Methods}

The estuarine clams, Katelysia opima were collected from Bhatye estuary, Ratnagiri. The animals were immediately brought to the laboratory and acclimatized for $4-5$ days in laboratory conditions. Medium sized healthy and active bivalves were used for experiments. Clams well acclimatized to the laboratory condition were grouped in tens and kept in plastic containers containing 5 liters filtered estuarine water. Static bioassay tests were conducted for 96 hours by using Cypermethrin (25\% EC). For every experiment, a control group of clam was also run simultaneously. For the formulation of test concentration, pilot experiment was conducted and range of concentration selected was such that it resulted in zero to total mortality. The formula used to prepare the pesticide solution is as follows:

$$
\text { No. of } \mathrm{ml} \text { for required volume }=\frac{\text { required } \mathrm{ppm} \times \text { required volume }}{\text { Stock solution }}
$$

The volume of the container was maintained at $5 \mathrm{~L}$ for each. Observations were made at $12,24,36,48,60,72$, 84 and 96 hours behavioural changes of the clams after introduction into different pesticide concentration were determined.

For the selection of test concentrations, some pilot tests were performed to determine the range of toxicity of the pesticide. The range of concentrations selected was such that it resulted in zero to hundred percent mortality for short term exposures. The $\mathrm{LC}_{50}$ value for each time period was estimated by a regression analysis determined for the log of concentrations and percentage survival of the clam. The percentage mortality in various concentrations at particular period were converted into probit values and plotted against the log of concentrations [11].

The toxicity tests were repeated three times and $\mathrm{LC}_{0}$ and $\mathrm{LC}_{50}$ values were determined. The regression equation between the log of concentration $(\mathrm{X})$ and probit mortality $(\mathrm{Y})$ were determined statistically for acute toxicity using the formula $\mathrm{Y}=\alpha+\beta \log (\mathrm{x})$ and $95 \%$ fiducial limits were established according to Finney [12].

Oxygen consumption experiments were performed in specially designed glass jars of one liter capacity fitted 
with rubber lid containing inlet and outlet rubber tubes. The marked clams were kept, one in each jar and immediately filled with filtered estuarine water through a siphon and then clamped at both the ends and were kept aside for one hour. Dissolved oxygen was determined by Winkler's method from the estuarine water [13]. The rate of oxygen consumption of the $\mathrm{LC}_{0}$ and $\mathrm{LC}_{50}$ groups of the clams along with control after every 12 hours time interval was determined. All the values were subjected to statistical analysis. Rate of oxygen consumption was calculated in terms of $\mathrm{ml} / \mathrm{hr} / \mathrm{gm}$ wet weight. Comparing the results with control, the changes in the rate of oxygen consumption from $\mathrm{LC}_{0}$ and $\mathrm{LC}_{50}$. The changes in the rate of oxygen consumption from $\mathrm{LC}_{0}$ and $\mathrm{LC}_{50}$ concentration were statistically calculated [14]. The experiment was repeated three times for confirmation of the results. Such experiments were performed during November to March 2012.

\section{Results}

During experimental period, clams showed no mortality up to $1.86 \mathrm{ppm}$. $10 \%$ mortality was found at $2.04 \mathrm{ppm}$.; whereas $20 \%, 30 \%, 40 \%, 50 \%, 60 \%, 70 \%$ and $80 \%$ mortality was found in 2.23, 2.41, 2.60, 2.79, 2.97, 3.16 and $3.53 \mathrm{ppm}$, respectively at the end of 96 hours (Table 1). The calculated $\mathrm{LC}_{50}$ value was $2.75 \mathrm{ppm}$ and the observed $\mathrm{LC}_{50}$ value was $2.79 \mathrm{ppm}$. The regression equation established was $\mathrm{Y}=0.6242+9.9484 \mathrm{x}$, the $95 \%$ fiducial limit was 1.7632 - $3.7368 \mathrm{ppm}$ for this season.

The measurement of the rate of oxygen consumption in Katelysia opima after acute exposure to Cypermethrin showed significant increase in $\mathrm{LC}_{0}$ group and significant decrease in $\mathrm{LC}_{50}$ group as observed in Table 2.

The control group of clam showed fluctuations in the rate of oxygen consumption between $0.217 \pm 0.0022$ to $0.326 \pm 0.0022 \mathrm{ml} / \mathrm{L} / \mathrm{hr} / \mathrm{gm}$ from zero to 96 hours. $\mathrm{In} \mathrm{LC}_{0}(1.86 \mathrm{ppm})$ group, clams exhibited fluctuations in the rate of oxygen consumption between $0.215 \pm 0.0027$ to $0.376 \pm 0.0018 \mathrm{ml} / \mathrm{L} / \mathrm{hr} / \mathrm{gm}$ during zero to 96 hours. There was a considerable increase from $0.215 \pm 0.0027$ to $0.376 \pm 0.0018 \mathrm{ml} / \mathrm{L} / \mathrm{hr} / \mathrm{gm}$ from zero to 60 hours. From 60 hours, there was a considerable decrease up to $0.297 \pm 0.0025 \mathrm{ml} / \mathrm{L} / \mathrm{hr} / \mathrm{gm}$ at the end of 96 hours. As compared to control, there was $6.44 \%, 2.30 \%, 1.26 \%$ and $0.92 \%$ ( $<$ < 0.001) decrease in oxygen uptake at the end of 84, 96, 72 and zero hours, respectively. There was an increase of $32.39 \%, 22.29 \%, 16.77 \%, 12 \%$ and $3.74 \%$ at the end of 60 , 48, 36, 24 and 12 hours, respectively. $\mathrm{In} \mathrm{LC}_{50}(2.79 \mathrm{ppm})$ group, the rate of oxygen consumption fluctuated between $0.174 \pm 0.0018$ to $0.356 \pm 0.0018 \mathrm{ml} / \mathrm{L} / \mathrm{hr} / \mathrm{gm}$ from zero to 96 hours. There was a considerable increase from $0.210 \pm 0.0154$ to $0.356 \pm 0.0018 \mathrm{ml} / \mathrm{L} / \mathrm{hr} / \mathrm{gm}$ at the end of 24 hours. It decreases from $0.247 \pm 0.0015$ to $0.217 \pm 0.0022$ from 36 hours to 48 hours and there was a decrease in the rate of oxygen consumption from 0.244 \pm 0.0031 to $0.174 \pm 0.0018$ from 60 to 96 hours. As compared to control, $42.94 \%, 42.76 \%, 35.96 \%, 26.68 \%$,

Table 1. Regression equations, 95\% fiducial limits with $\mathrm{LC}_{50}$ values for Katelysia opima exposed to Cypermethrin.

\begin{tabular}{ccccc}
\hline $\mathbf{Y}=\boldsymbol{\alpha}+\boldsymbol{\beta} \mathbf{X}$ & $\mathbf{9 5 \%}$ fiducial limit (ppm) & $\mathbf{L C}_{\mathbf{0}}(\mathbf{p p m})$ & Calculated $\mathbf{L} \mathbf{C}_{\mathbf{5 0}}(\mathbf{p p m})$ & Observed LC $_{\mathbf{5 0}}(\mathbf{p p m})$ \\
\hline $0.6242+9.9484 \mathrm{x}$ & $1.7632-3.7368$ & 1.86 & 2.75 & 2.79 \\
\hline
\end{tabular}

Table 2. Rate of oxygen consumption (ml/L/hour/gm. Wet wt.) in Katelysia opima exposed to different concentrations of Cypermethrin after acute exposure during November to March, 2012.

\begin{tabular}{|c|c|c|c|c|c|c|c|c|c|}
\hline \multirow{2}{*}{$\begin{array}{l}\text { 亏े } \\
\text { ठ }\end{array}$} & \multicolumn{9}{|c|}{ Exposure period } \\
\hline & 0 Hrs & 12 Hrs & $24 \mathrm{Hrs}$ & 36 Hrs & $48 \mathrm{Hrs}$ & 60 Hrs & $72 \mathrm{Hrs}$ & 84 Hrs & $96 \mathrm{Hrs}$ \\
\hline
\end{tabular}

$$
\begin{aligned}
& \text { 苞 } 0.217 \pm 0.00220 .294 \pm 0.00250 .325 \pm 0.00270 .304 \pm 0.00150 .296 \pm 0.00210 .284 \pm 0.00150 .317 \pm 0.00250 .326 \pm 0.00220 .304 \pm 0.0033
\end{aligned}
$$

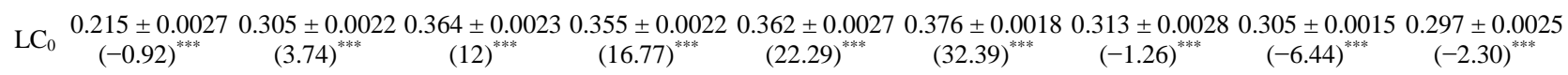

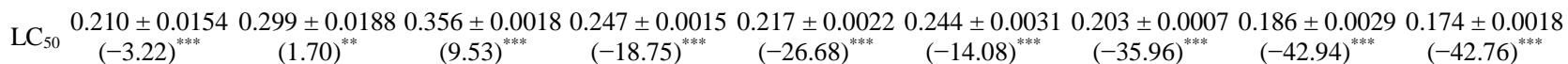

Values in parenthesis are percent change. $\pm=$ S.D. of five trials. ${ }^{*}=\mathrm{p}<0.05,{ }^{* *}=\mathrm{p}<0.01,{ }^{* * *}=\mathrm{p}<0.001$. 
$18.75 \%, 14.08 \%$ and $3.22 \%(\mathrm{p}<0.001)$ decrease at the end of 84, 96, 72, 48, 36, 60 and zero hours, respectively. There was $9.53 \%(\mathrm{p}<0.001)$ and $1.70 \%(\mathrm{p}<0.01)$ increase at the end of 24 and 12 hours respectively.

\section{Discussion}

In the present study, the control group of clams showed increased oxygen uptake. As compared with control group of clams, $\mathrm{LC}_{50}$ group showed decreased oxygen uptake. The observed decrease is attributed to variation in the volume of water ventilated through the gills, caused by the intermittent closure and opening of the shell valves. Here the main factor responsible for decreased oxygen uptake was coagulation of mucus on gills due to Cypermethrin exposure. Coagulation of mucus causes reduction in the effective transfer of oxygen to internal tissues, adversely affects the absorption of oxygen from the ambient medium. The stiff suppression in the rate of oxygen consumption was probably due to the reduced efficiency of gills. In the present study, considerable mucus secretion was found in lethal concentration during the experimental period. These fluctuations in the oxygen uptake rate in estuarine clams exposed to Cypermethrin are due to variations in gill ventilation rate coupled with the concentration of pollutant in water and the efficiency of assimilation of oxygen via the gills and also the length of time during which the shell valve is closed [15]. In Gafrarium diverticulum suppression of oxygen consumption and rate of filtration was observed after 96 hours Benzene and gear oi-WSF exposure [16]. Reduction inoxygen consumption was reported in $\mathrm{LC}_{50}$ group of fresh water Lamellibranch marginalis from Godavari [17]. Similar observations were observed in various animals at different sub-lethal concentrations of heavy metal and or pesticides [18]-[23].

To cope with this hypoxia, clams tried to filter more water. High oxygen consumption rate showed by the Clams from $\mathrm{LC}_{50}$ group indicated a high energy demand. As compared to the control group, clams treated with $\mathrm{LC}_{0}$ concentration showed a slight elevation in oxygen consumption after initial 12 hours exposure. These findings relate with the findings of many workers. It was observed that oxygen consumption increased in $P$. viridis exposed to low concentrations of Ag, while concentrations above $0.01 \mathrm{ppm}$, oxygen consumption sharply decreased [24]. In $L$. marginalis pesticide induced increased oxygen uptake was observed. The decrement may be due to the respiratory distress as a consequence of the impairment of oxidative metabolism [25].

The effect of Cypermethrin showed copious secretion of mucous. The high mucous secretion deposited on the respiratory surface may interfere the rate of oxygen diffusion and therefore oxygen consumption can be decreased. The bivalves usually try to avoid toxicants and in doing so, they can minimize their metabolic activity. The metabolic stress of the drug may decrease the rate of oxygen consumption. Respiratory inefficiency and ultimately total respiration breakdown can also be due to the formation of mucous on the respiratory organs in case of pollutant exposure to Bellamya bengalensis [26]. While studying the effect of heavy metal on the histological structure of the gills of crustaceans, the decline in the rate of oxygen consumption was due to the formation of coagulated mucous over the gills and body surface of the crab [27]. The pollutant treated molluscs secrete mucous in large amount to reduce exposure to environmental stress or pollutant [28]. In the present investigation the decrease in the rate of oxygen consumption in the bivalve treated with Cypermethrin may be due to mucous secretion on body surface, pesticide induced respiratory stress and impaired oxidative metabolism.

\section{References}

[1] Nagarathnamma and Ramamurthy (1983) In Vivo Recovey of Acetylcholinesterase Activity from Methyl Parathion Induced Inhibition in the Freshwater Teleost, Cyprinus carpio. Current Science, 52, 74-75.

[2] Jothinarendiran, N. (2012) Effect of Dimethoate Pesticide on Oxygen Consumption and Gill Histology of the Fish, Channa punctatus. Current Biotica, 5, 500-507.

[3] Mathivanan, R. (2004) Effect of Sublethal Concentration of Quinolphos in Selected Respiratory and Biochemical Parameters in the Freshwater Fish, Oreochromis mossambicus. Journal of Eco Toxicology and Environmental Monitoring, 14, 57-64.

[4] Welsh, J.H. and Smith, R.I. (1960) Laboratory Exercise in Invertebrate Physiology. Burgers Publishing Company, Minneapolis.

[5] Tyagi, P., Dharam, B., Choudhary, R. and Sawhney, B.L. (2000) Physico Chemical Quality of Ground Water in Industrial Areas of India: A Review. Poll Research, 19, 443-445.

[6] Rao, D.M.R. (1989) Studies on the Relative Toxicity of Endosulphan to the Indian Major Carps Catla catla with Special Reference to Some Biochemical Changes Induced by the Pesticide. Pesticide Biochemistry and Physiology, 33, 
220-229. http://dx.doi.org/10.1016/0048-3575(89)90120-X

[7] Hughes, G.M. (1976) Effect of Pollutants on Aquatic Organisms. Applied Physiological Measurement, Polluted Fish Respiratory Physiology in Lockwood, Cambridge University Press, Cambridge, 163-183.

[8] Wright, D.A. (1978) Heavy Metal Accumulation by Aquatic Invertebrates. Applied Biology, 3, 331-394.

[9] Mukke, V.K. and Chinte, D.N. (2012) Effect of Sub Lethal Concentration of Mercury and Copper on Oxygen Consumption of Freshwater Crab, Barytelphusa guerini. Recent Research in Science and Technology, 4, 15-17.

[10] Shelke, A.D. and Wani, G.P. (2005) Respiratory Response of a Fresh Water Teleost Fish, Amblypharyngodon mola. Journal of Aquatic Biology, 20, 193-196.

[11] Ghosh, T.K. and Chatterjee, S.R. (1985) Effect of Chromium on Tissue Energy Reserve in Fresh Water Fish, Sarotherodon mossambicus. Journal of Environment and Ecology, 3, 178-179.

[12] Finney, D.J. (1971) Probit Analysis. Cambridge University Press, London, 25-66.

[13] Welsh, J.H. and Smith, R.I. (1961) Laboratory Exercise in Invertebrate Physiology. Burgess Publishing Co., Minneapolis.

[14] Doudeswell, W.H. (1957) Practical Animal Ecology. Methum and Co. Ltd., London, 265-275.

[15] Rajalakshmi, P. and Mohandas, A. (1998) Acute Effect of Pesticides Stress on the Rate of Oxygen Uptake in the Freshwater Mussel, Lamellidens corrianus. Proceedings of Academic Environmental Biology, 7, 45-49.

[16] Tendulkar, S.P. and Kulkarni, B.G. (1998) Physiological Responses of a Clam Grafrarium diverticulum (Gmelin) to Xylene, Benzene and Gear Oil-WSf. Indian Journal of Marine Sciences, 27, 492-495.

[17] Muley, D.V. and Mane, U.H. (1987) Malathion Induced Changes in Oxygen Consumption in Two Species of Freshwater Lamellibranch mollusks from Godaveri River Maharashtra State, India. Indian Journal of Environment Biology, 8, 267-275.

[18] Baby, K.V. and Menon, N.R. (1986) Oxygen Uptake in the Brown Mussel, Perna indica under Sublethal Metals of Mercury, Cadmium and Zinc. Indian Journal of Marine Sciences, 15, 127-128.

[19] Kapoor, S.G. and Lomte, V.S. (1987) Effect of Toxic Compounds (HgCl2 and CuSO4) on Oxygen Consumption of the Freshwater Mussel, Indonaia caeruleus. Proceedings of National Symposium on Ecotoxicology, 134-136.

[20] Prakasam, V.R., Johnikutty, P.S., Sajee, P.G. and George P.M. (1989) Combined Effect of Hg and Zn in Modifying the Rate of Ciliary Activity of Lamellidens marginalis. Journal of Environmental Biology, 10, 211-215.

[21] Muley, D.V. (1991) Pesticide Toxicity to Freshwater Lamellibranch Mollusks from Maharashtra State, India. Proceedings of 10th International Malacol Congress, 207-211.

[22] Savant, K.B. and Amte, G.K. (1992) Respiratory Response of Estuarine Crab, Ilyoplax gangetica Exposed to Three Metallic Chemicals. Journal of Ecotoxicology and Monitoring, 2, 259-262.

[23] Sultana, M. and Lomate, V.S. (1998) Oxygen Consumption under Mercury and Zinc Stress in Lamellidens marginalis. Ecotoxicological Environmental Monitoring, 9, 9-12.

[24] Mathew, R. and Menon, N.R. (1983) Oxygen Consumption in Tropical Bivalves Perna viridis and Meretrix casta (Chem.) Exposed to Heavy Metals. Indian Journal of Marine Sciences, 12, 57-59.

[25] Prashanth, M.S., David, M. and Kuri, R.C. (2003) Effect of Cypermethrin on Toxicity and Oxygen Consumption in the Freshwater Fish, Cirrhinus mrigala. Journal of Ecotoxicology and Environmental Monitoring, 13, 271-277.

[26] Lomte, V.S. (1984) Effect of Toxic Compounds on Oxygen Consumption in the Freshwater Bivalve Corbicula regularis. Comparative Physiology and Ecology, 7, 31-33.

[27] Khan, A., Patel, R.T. and Sheikh, F.I. (2000) Effect of Mercuric Chloride on the Gills of the Freshwater Crab, Barytelphusa guerini. Proceedings of the International Conference on Probing in Biological System, Mumbai, 7-11 February 2000, 134.

[28] Sontakke, Y.B. (1992) Some Physiological Variations Associated with Pollutant Treatment in the Snail, Thiara tuberculata. Ph.D. Thesis, Marathwada University, Aurangabad. 
Scientific Research Publishing (SCIRP) is one of the largest Open Access journal publishers. It is currently publishing more than 200 open access, online, peer-reviewed journals covering a wide range of academic disciplines. SCIRP serves the worldwide academic communities and contributes to the progress and application of science with its publication.

Other selected journals from SCIRP are listed as below. Submit your manuscript to us via either submit@scirp.org or Online Submission Portal.
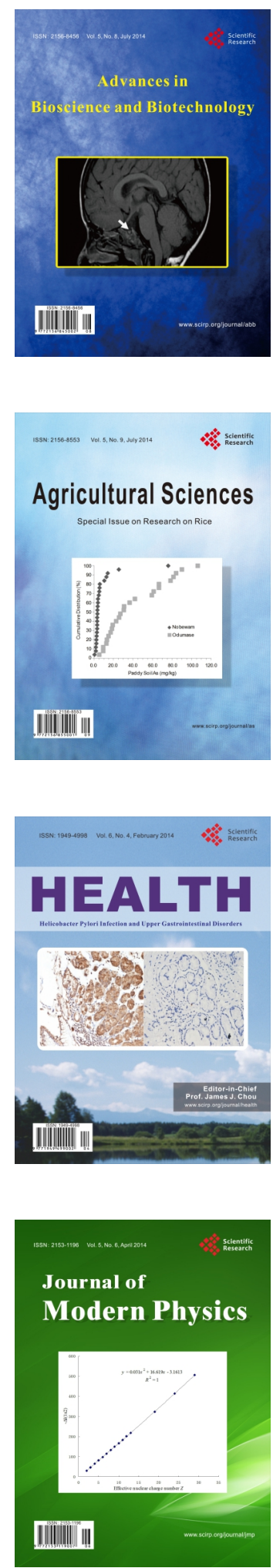
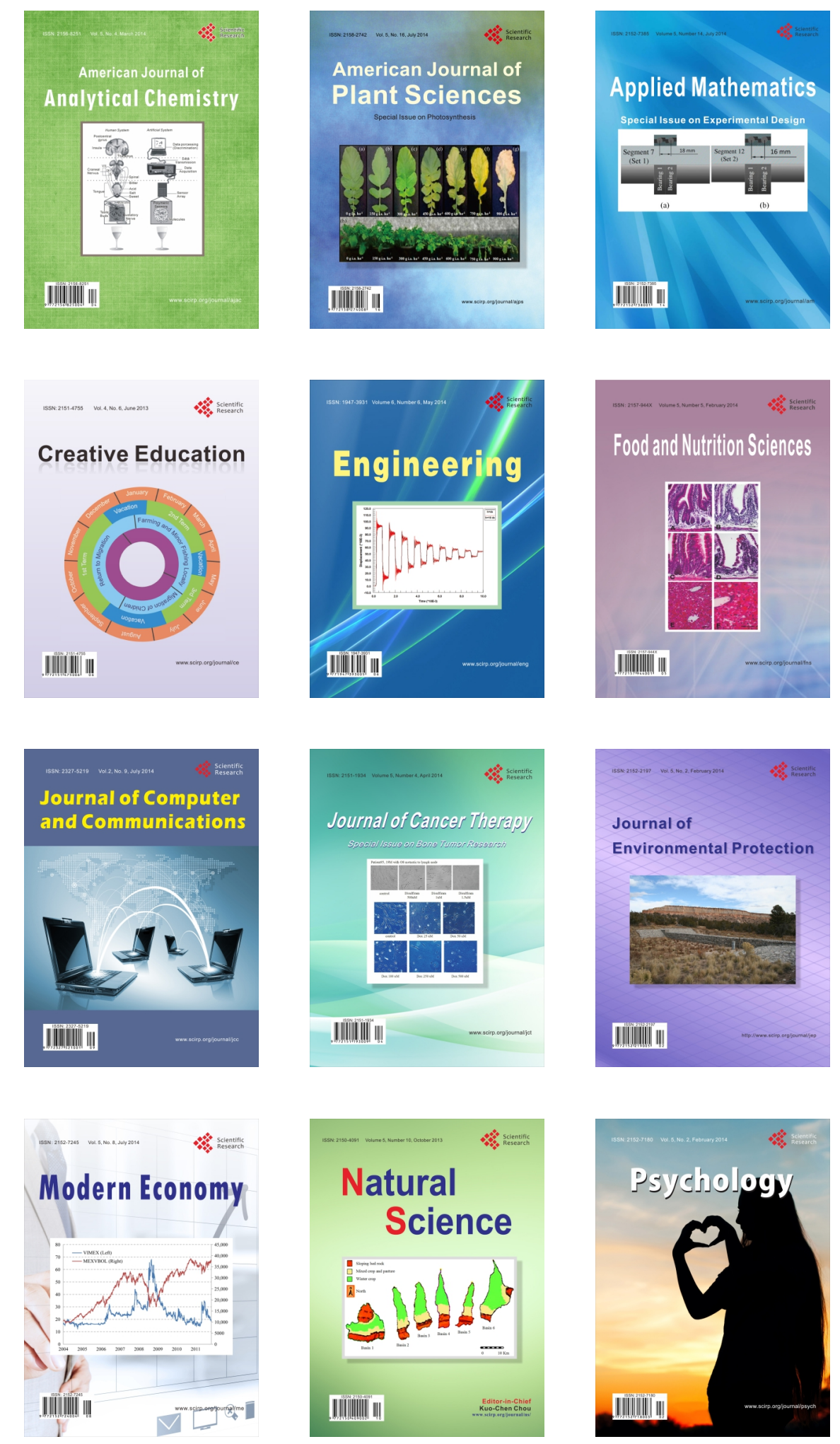